\title{
Methodology for Technical Feasibility Analysis in the Installation of Microgrids
}

\author{
Maria Isabel Carvajal ${ }^{1}$, Eduardo Gómez-Luna² and Eduardo Marlés Sáenz ${ }^{3}$ \\ ${ }^{1}$ Universidad del Valle Escuela de Ingenieria, Electrica y Electrónica Facultad de Ingenieria. Gralta Carrera 13 No. 100-00, Cali, \\ Colombia \\ ${ }^{2}$ Potencia y Tecnologías Incorporadas S.A Grupo de Investigación, GITICAP Cra. 56 No. 2-50. Avenida Guadalupe. Cali, Colombia \\ ${ }^{3}$ Universidad del Valle Escuela de Ingeniería, Eléctrica y Electrónica Facultad de Ingeniería Grupo de Investigación en Alta Tensión \\ Gralta Carrera 13 No. 100-00, Cali, Colombia
}

Received 19 March 2019; Accepted 8 September 2019

\begin{abstract}
The proposal of a methodology for the analysis of the technical feasibility in the installation of Microgrids (MG's) is realized, which shows in several steps the necessary parameters to analyze and determine the viability of a Microgrid (MG) project in a determined area, with a specific demand and objectives. The methodology is based on a critical review of the different cases of MG's implemented around the world and different techno-economic feasibility study of MG systems.
\end{abstract}

Keywords: Microgrids, Distributed Generation, Renewable Energy Resources, Technical Feasibility

\section{Introduction}

The increase of electric demand worldwide and the need to reduce the environmental impact caused by conventional energy sources, causes the increase in the demand for Renewable Energy Sources (RES) and therefore the need to have Distributed Generation DG in the power system. The implementation of Microgrids allows the insertion of renewable sources of energy, giving the power system greater reliability and failure support, in addition to allowing a reliable supply of energy to those areas that do not count with continuous power supply due to their difficult acces [1]. As shown in Fig. 1, a MG is a set of DG units, loads, storage system and an intelligent control system, having the possibility of being connected to the main grid or been in island mode.

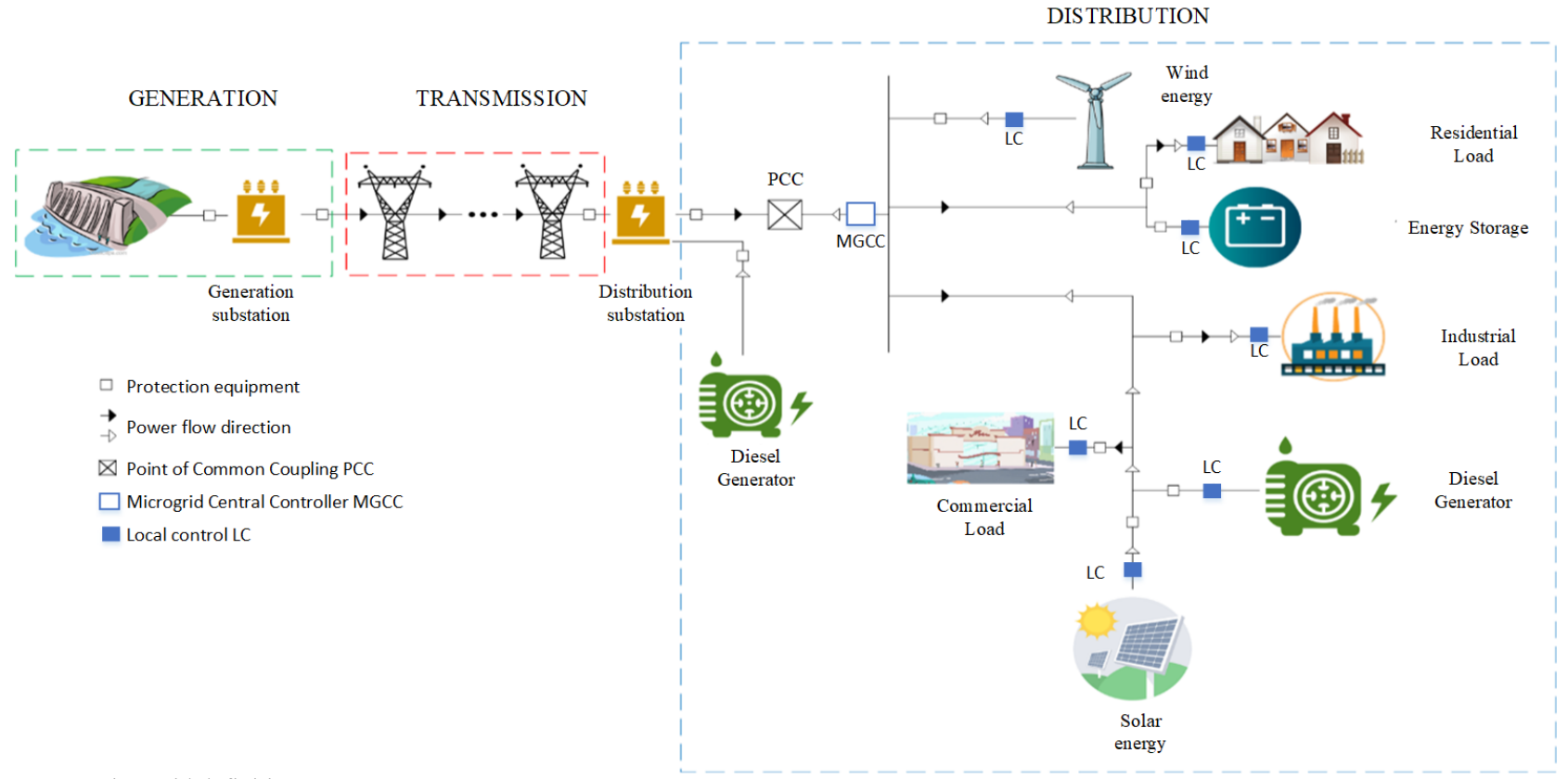

Fig. 1. Microgrid definition

Currently, there aren't standards that define the design,

*E-mail address: vkanak@teiemt.gr

ISSN: 1791-2377 @ 2019 School of Science, IHU. All rights reserved. doi:10.25103/iestr.125.20 construction and operation of a MG in an integral manner, therefore there are no procedures to evaluate the feasibility of implementing a $\mathrm{MG}$ in a specific place with specific conditions. Therefore, the main objective of this article is the presentation of a methodology that allows the analysis of the 
Maria Isabel Carvajal, Eduardo Gómez-Luna and Eduardo Marlés Sáenz/

Journal of Engineering Science and Technology Review 12 (5) (2019) 176 - 187

technical feasibility in the installation of MG's, based on the revision and analysis of the references summarized in Fig. 2.

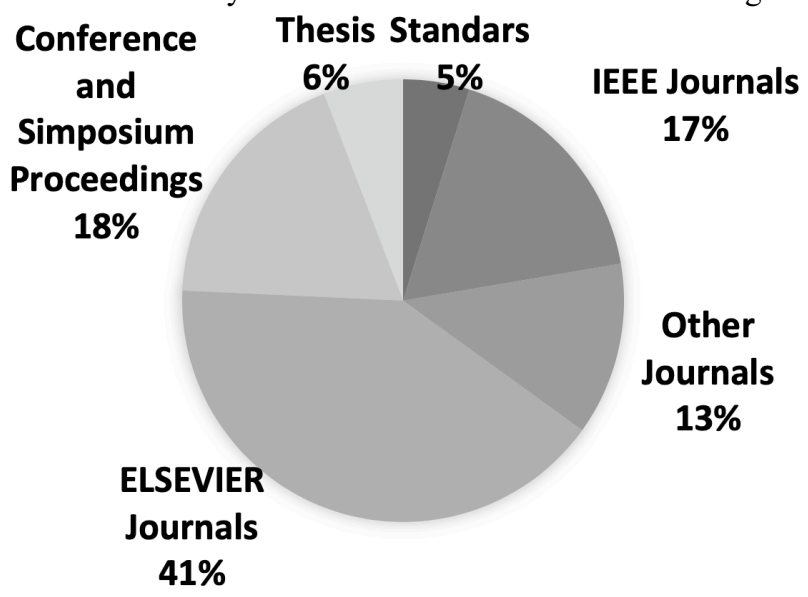

Fig. 2. Summarized references.

\section{Propoused methodology}

The proposed methodology is based on the critical review of MG implementation cases around the world and different

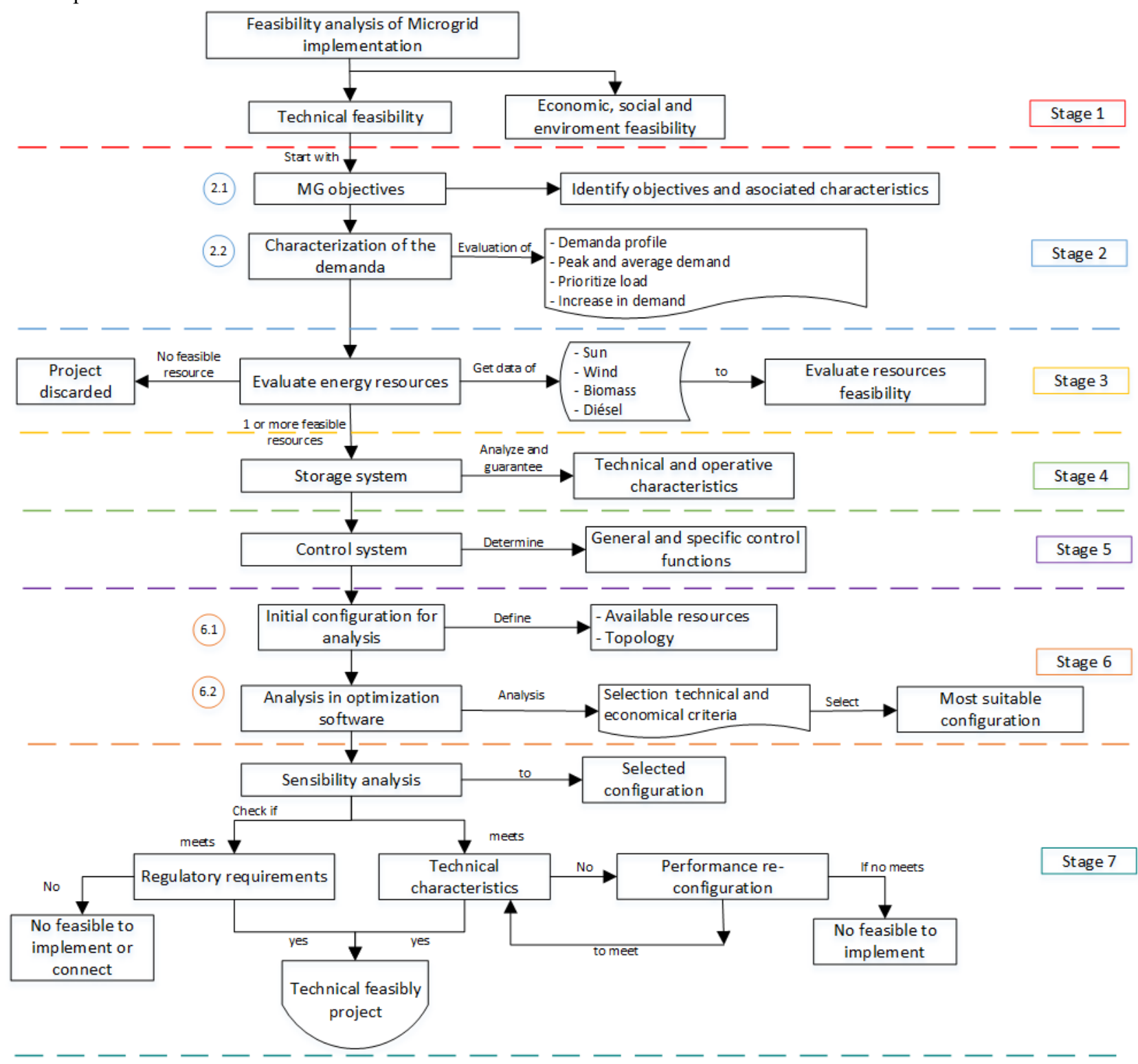

methodologies of technical-economic feasibility analysis to MG projects. According to Fig. 3, the methodology is composed of 8 stages, which allows to evaluate and analyze the technical feasibility of each component of a MG. In Stage 1, the methodology approach is presented, aimed at the evaluation and analysis of technical feasibility in MG's, highlighting that economic, social and environmental feasibility must also be evaluated; Stage 2 focuses on determining the objectives (Stage 2.1) and characterizing the demand to be met by the MG (Stage 2.2); in Stage 3, the feasibility of the available DG resources is evaluated and are presented the technical characteristics to be guaranteed for its implementation; Stage 4 represents the technical and operational characteristics to guarantee for a feasible Storage System, Stage 5 represents the functions thet musth fulfill the intelligent control system; in Stage 6, the initial configuration of the $\mathrm{MG}$ is obtained (Stage 6.1) and the software optimization process is carried out, obtainning a feasible final configuration (Stage 6.2); finally, in Stage 7, it is carried out the sensitivity analysis for the final configuration, and the verification of technical and normative factors.

Fig. 3. Flow diagram of the proposed methodology. 


\section{$\checkmark$ Stage 1. Previous feasibility studies}

For the implementation of a MG, it is necessary to carry out preliminary studies of technical, economic, social and environmental feasibility to determine if the project is being carried out or not. This methodology focuses on the analysis of the technical feasibility, for which it takes into account the evaluation and availability of energy resources, the dynamics of demand, infrastructure and necessary space, technical and operational characteristics of each component of the MG, characteristics of the technology and equipment of generation and storage required, parameters for sizing and identification of regulatory requirements to determine it's implementation.

\section{$\checkmark$ Stage 2. Definition of objectives and characterization of the demand}

In this stage are defined the specific objectives that are intended to be met when implementing a $\mathrm{MG}$ and the demand to be met by the MG is characterized, therefore it is divided into Stage 2.1 and Stage 2.2 as follows.

\section{$\checkmark$ Stage 2.1. Definition of objectives}

The objective of a MG is completely subjective because it depends on the entity or user that intends to carry out the implementation project. The importance of determining the specific objectives lies in the fact that each one define technical and operational characteristics that the MG must meet to achieve thes objective. Therefore in the Table. 1, the general objectives of a MG with its respective technical and operative characteristics are presented. The objectives presented are the most common within the cases of implementation and feasibility of MG's reviewed.

Table 1. Objectives of the integration of MG's in the conventional electrical network

\begin{tabular}{|c|c|c|}
\hline Objective & Technica characteristics & $\begin{array}{c}\text { Operatives } \\
\text { characteristics }\end{array}$ \\
\hline $\begin{array}{l}\text { Backup to } \\
\text { failures }\end{array}$ & $\begin{array}{l}\text { Switch disconnection / } \\
\text { reconnection } \\
\text { Requires storage } \\
\text { Diesel generator } \\
\text { (optional) }\end{array}$ & $\begin{array}{l}\text { Connected mode: } \\
\text {-Load sharing. } \\
\text { - Sell energy to the grid } \\
\text { (optional). } \\
\text { Island mode: } \\
\text {-Load shedding. } \\
\text { Black start. } \\
\text { Synchronization and } \\
\text { reconnection to the grid. }\end{array}$ \\
\hline $\begin{array}{c}\text { Increase of } \\
\text { reliability in } \\
\text { supply } \\
\end{array}$ & $\begin{array}{l}\text { Diesel generator as backup } \\
\text { (optional) } \\
\text { Requires storage }\end{array}$ & $\begin{array}{l}\text { Island mode: } \\
\text {-Load shedding. } \\
\text {-Black start } \\
\end{array}$ \\
\hline $\begin{array}{l}\text { Reduction of } \\
\text { costs and } \\
\text { peak } \\
\text { demand }\end{array}$ & $\begin{array}{l}\text { Bi-directional inverter } \\
\text { Requires storage } \\
\text { Diesel generator } \\
\text { (optional) }\end{array}$ & $\begin{array}{l}\text { Connected mode: } \\
\text { - Sell / buy to the grid. } \\
\text { - Peak-shaving. } \\
\text { - Load shifting. } \\
\text { - Load sharing. } \\
\text { Island mode: } \\
\text {-Optimize use of Diesel. } \\
\text { - Load shedding. } \\
\text { - Lower operation cost. }\end{array}$ \\
\hline
\end{tabular}

\begin{tabular}{|c|c|c|}
\hline $\begin{array}{l}\text { Optimizatio } \\
n \text { and energy } \\
\text { efficiency }\end{array}$ & $\begin{array}{l}\text { Diesel generator (minor } \\
\text { use possible) } \\
\text { Requires storage }\end{array}$ & $\begin{array}{l}\text { Sell / buy to the grid. } \\
\text { MPPT scheme for DG units } \\
\text { Connected mode / Island } \\
\text { mode: } \\
\text {-Load shifting. } \\
\text {-Load sharing. }\end{array}$ \\
\hline $\begin{array}{l}\text { Remote } \\
\text { Mode }\end{array}$ & $\begin{array}{l}\text { Diesel generator as backup } \\
\text { Requires storage }\end{array}$ & $\begin{array}{l}\text {-Load shedding } \\
\text {-Load shedding } \\
\text {-Black start } \\
\text { - MPPT scheme } \\
\text { - Optimize Diesel use }\end{array}$ \\
\hline $\begin{array}{l}\text { Reduction of } \\
\text { emissions / } \\
\text { Reduce } \\
\text { pollution }\end{array}$ & $\begin{array}{l}\text { Implement renewable DG } \\
\text { Requires storage }\end{array}$ & $\begin{array}{l}\text { Optimization and less use } \\
\text { of diesel or conventional } \\
\text { generatorsOptimization } \\
\text { and less use of diesel or } \\
\text { conventional systems }\end{array}$ \\
\hline
\end{tabular}

Stage 2.2: Characterization of the demand

It is necessary to characterize the loads that will be part of the $\mathrm{MG}$, to know its dynamics and historical behavior, to meet the demand [2], [3], which why in the Table 2 is propose the characteristics to analyze of the load and its importance.

In Fig. 4, are defined 3 operating schemes related to the demand, Load shedding [4]-[6], Load sharing [7], [8] and Load shifting [9]; which for their execution require the knowledge, analysis and classification of the demand. These schemes become important later when evaluating the MG Control System.

Table 2. Data for demand evaluation [2], [3], [10]-[13].

\begin{tabular}{|c|c|c|}
\hline $\begin{array}{c}\text { Analysis } \\
\text { parameters }\end{array}$ & Characteristic & Importance \\
\hline Demand profile & $\begin{array}{l}\text { - Change in demand } \\
\text { on an average day. } \\
\text { - Data not less than } \\
\text { one year. } \\
\text { - It takes into account } \\
\text { climate change / } \\
\text { seasons. }\end{array}$ & $\begin{array}{l}\text { - Know the dynamic of the } \\
\text { load } \\
\text { - Identify increase or } \\
\text { decrease due to cultural, } \\
\text { climatic or industrial } \\
\text { factors. } \\
\text { - Input data optimization } \\
\text { software. } \\
\text { - Sizing of DG units and } \\
\text { storage. }\end{array}$ \\
\hline $\begin{array}{c}\text { Average } \\
\text { demand and } \\
\text { peak demand }\end{array}$ & $\begin{array}{l}\text { - Maximum load } \\
\text { consumption in the } \\
\text { year. } \\
\text { - Average } \\
\text { consumption }\end{array}$ & $\begin{array}{l}\text { - Input data for the } \\
\text { optimization software. } \\
\text { - Sizing of DG units and } \\
\text { storage. }\end{array}$ \\
\hline Classify demand & $\begin{array}{l}\text { - Classify critical and } \\
\text { non-critical loads. } \\
\text { - Its importance, } \\
\text { power and role are } \\
\text { taken into account. } \\
\text { - It is classified by an } \\
\text { algorithm }\end{array}$ & $\begin{array}{l}\text { - To maintain the stability } \\
\text { of the MG by disconnecting } \\
\text { non-critical load. } \\
\text { - It has associated operation } \\
\text { schemes. }\end{array}$ \\
\hline $\begin{array}{l}\text { Demand } \\
\text { increase }\end{array}$ & $\begin{array}{l}\text { - Define an adequate } \\
\text { percentage of increase } \\
\text { in demand. } \\
\text { - Minimum } 15 \% \\
\text { increase. }\end{array}$ & $\begin{array}{l}\text { Ensure the stability of the } \\
\text { MG and the long-term } \\
\text { supply. }\end{array}$ \\
\hline
\end{tabular}




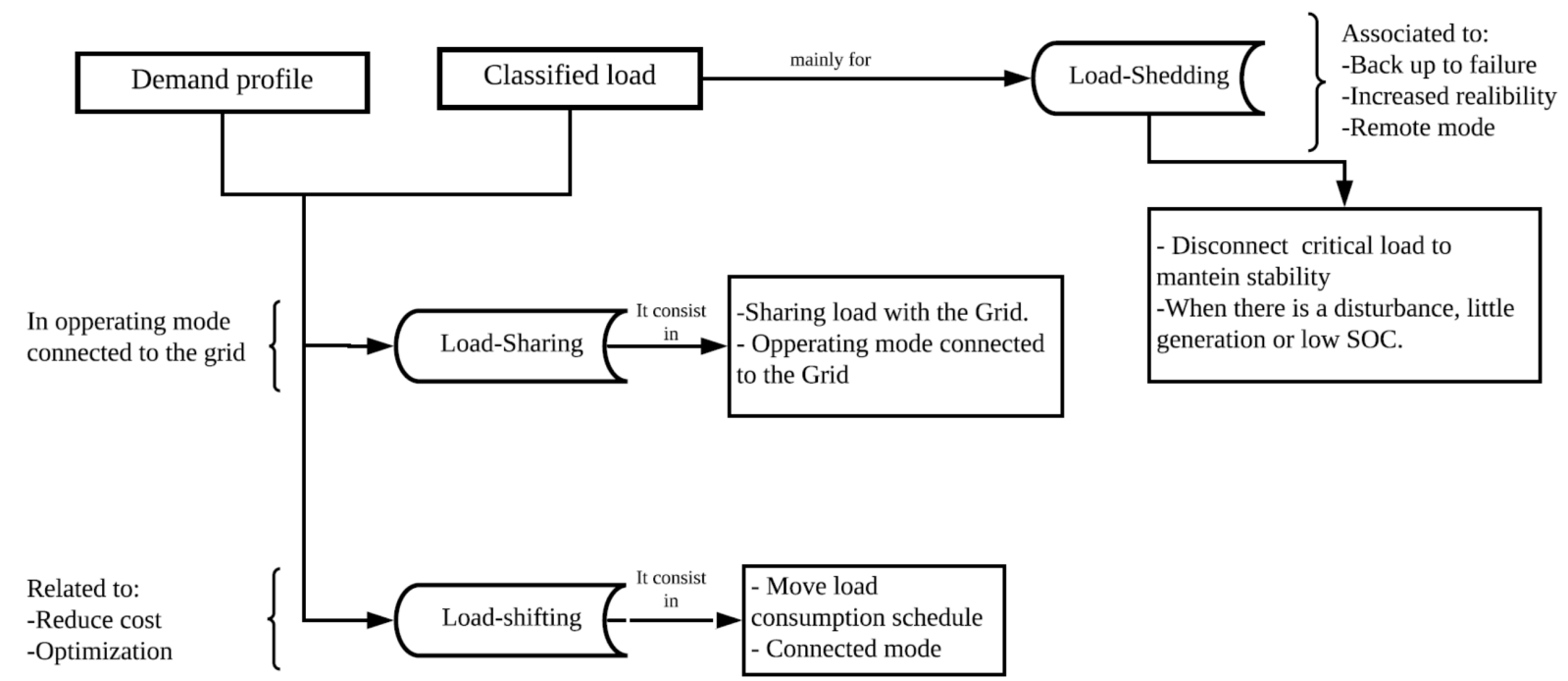

Fig. 4. Operating schemes related with the demand [4]-[9].

\section{$\checkmark$ Stage 3: Evaluation of energy sources}

In this stage, the necessary information is collected about each available resource for its evaluation, in which the implementation or not of the resource is defined, and the technical and control characteristics that must be guaranteed for its proper functioning are presented. According to the literature reviewed and the renewable global status report REN21 [14], the most reported DG resources are evaluated below.

\section{- Solar resource}

For the evaluation of this resource, in the

Table. 3, the necessary data are presented for the determination of the feasibility, evaluation and analysis of the resource. Once the necessary data is available, we proceed to determine if it is feasible to implement or not, by evaluating the average radiation on site, as proposed in Fig. 5.

Table. 3. Main data for solar resource evaluation.

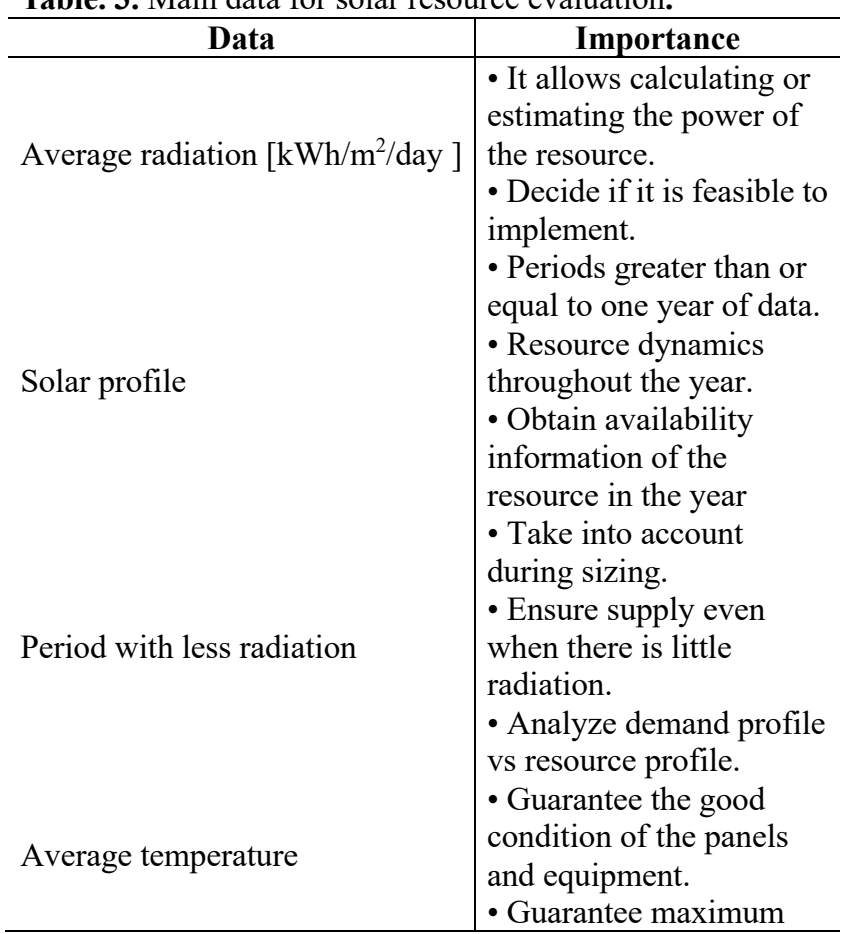

efficiency and power output.

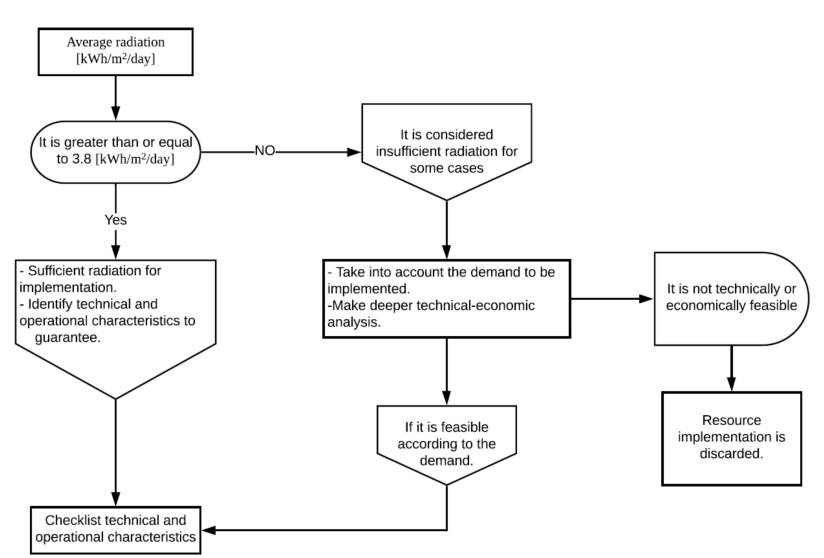

Fig. 5. Solar resource evaluation according to average radiation.

Once the implementation of the resource is defined, the technical and operative characteristics that must be guaranteed in the installation of the system to ensure its feasibility and correct operation are presented in the Table 4.

Table 4. Technical and operative characteristics to be guaranteed in the implementation [3], [15]-[20].

\begin{tabular}{l|l}
\hline \multicolumn{1}{c}{ Characteristics } \\
\hline \multicolumn{1}{c}{ Technical } & \multicolumn{1}{c}{ Control / operatives } \\
\hline $\begin{array}{l}\text { Define connection voltage. } \\
\text {-Influences number of panels per } \\
\text { arrangement }\end{array}$ & $\begin{array}{l}\text { Implement MPPT scheme. } \\
\text {-Find point of maximum } \\
\text { efficiency. } \\
\text {-It increases costs. } \\
\text { Define available area for panels: } \\
\text {-Guarantee infrastructure quality. }\end{array}$ \\
$\begin{array}{l}\text { Shadow factor, ensure that there is no } \\
\text { shadow over the defined area. }\end{array}$ \\
$\begin{array}{l}\text { Assign an average panel angle of } \\
\text { incidence. }\end{array}$ \\
$\begin{array}{l}\text { Ensure that the average temperature does } \\
\text { not exceed the panel's nominal value. } \\
\begin{array}{l}\text { Prevent presence or deposition of dust or } \\
\text { dirt on the panel. }\end{array}\end{array}$ \\
$\begin{array}{l}\text { Requires inverter or converter regardless } \\
\text { of the configuration. }\end{array}$ \\
\hline
\end{tabular}

\section{- Wind resource}


Maria Isabel Carvajal, Eduardo Gómez-Luna and Eduardo Marlés Sáenz/

Journal of Engineering Science and Technology Review 12 (5) (2019) 176 - 187

For the evaluation of the wind resource, Table 5 presents the necessary data that the user must know, to analyze the availability of the resource in the implementation area, and the importance of each parameter in the evaluation process.

Table 5. Main data for evaluation of the wind resource and its importance [20].

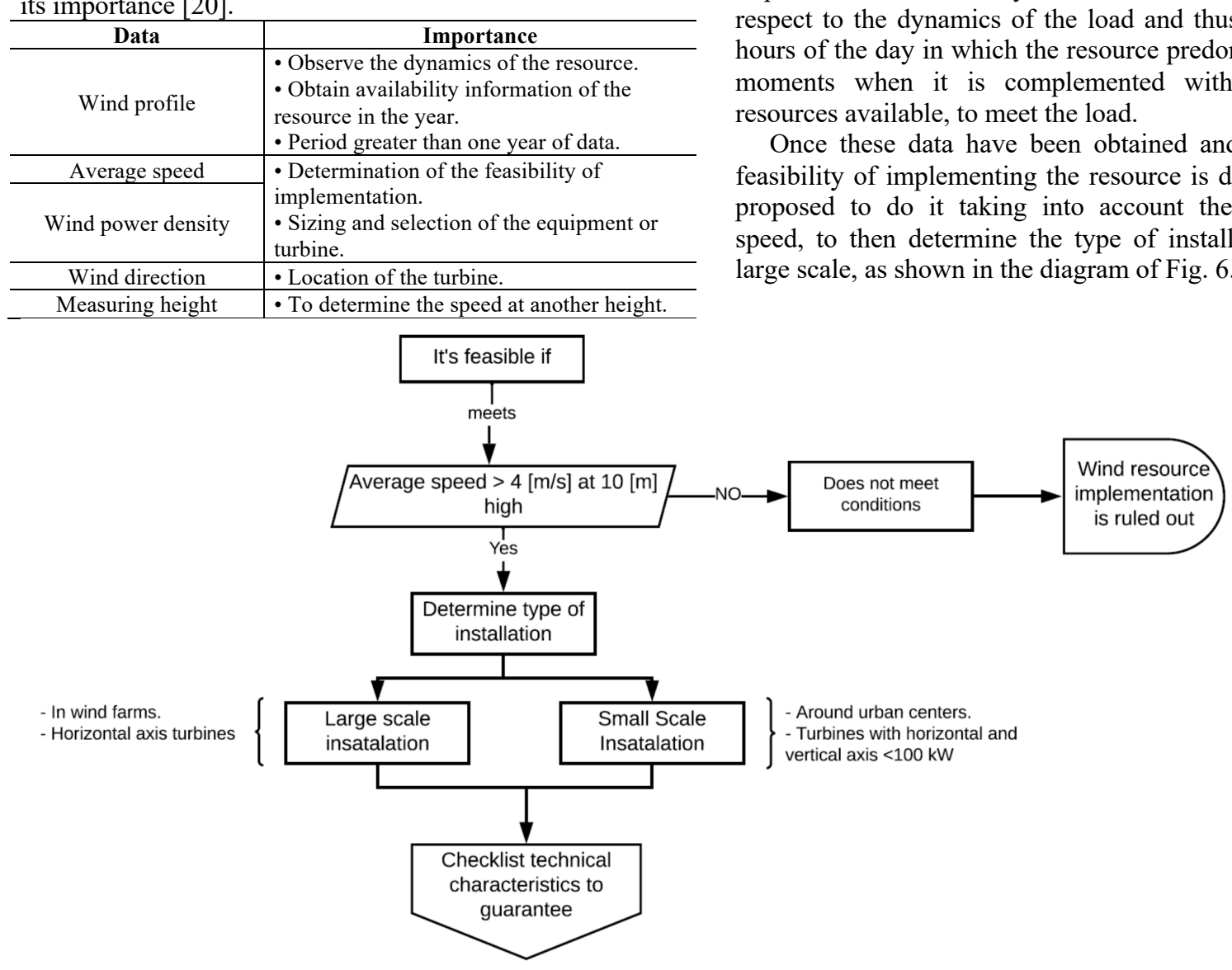

Fig. 6. Wind resource evaluation according to average speed in site [18], [21]-[24].

The determination of wind resource feasibility according to the speed, is not enough to analyze its feasibility, in addition to this, different technical characteristics shown in Table 6 must be guaranteed, to ensure its correct operation.

Table 6. Technical and operational characteristics to be guaranteed in wind resource implementation [21], [23], [25]. Technical characteristics

Turbine speed that produces maximum energy equal to the average speed of the place.

-Guarantee greater production as long as possible...

Analyze periods of non-operation to ensure a greater capacity factor:

-Speed $<$ Vcut-in (where Vcut-in is the turbine start speed)

-Speed $>$ Vcut-out (where Vcut-out is the turbine stop speed)

Appropriate location when there are numerous turbines, taking into account the wake effect, and the roughness of the wind.

Ensure perpendicular location of the turbine to the wind direction to extract maximum energy.

Locate the turbines where structures or relief do not hinder the flow of wind.

-For small scale, locate the turbines on the outskirts of urban centers (where condition is met)

\section{- Biomass resource}

This energy resource is obtained from the production of waste from different origins, such as: crop residues, animal waste, municipal solid waste and forest waste, which are called biomass, and are converted by different processes into

\begin{tabular}{l|l}
\hline & $\bullet$ Equipment selection. \\
\hline Period with lower speed & $\begin{array}{l}\bullet \text { Take into account during sizing. } \\
\bullet \text { Ensure supply even when there is low speed }\end{array}$ \\
\hline Analyze speed vs height & $\bullet$ Observe that higher, higher speed. \\
\hline
\end{tabular}

The wind profile, such as the solar profile, is of great importance for the analysis of resource availability with respect to the dynamics of the load and thus determine the hours of the day in which the resource predominates and the moments when it is complemented with other energy sources available, to meet the load.

Once these data have been obtained and analyzed, the 列 to do it taking into account the average wind peed, to then determine the type of installation, small or arge scale, as shown in the diagram of Fig. 6. thermal energy, electrical energy or as fuel [26]. Table 7 presents the data to be taken into account to evaluate the availability of animal residues, agricultural and energy crop residues, as a generation resource.

Table 7. Relevant data in the analysis for different waste [26], [27]

\begin{tabular}{|c|c|c|}
\hline \multicolumn{3}{|c|}{ Relevant data } \\
\hline Animal waste & Agricultural waste & $\begin{array}{c}\text { Residues of energy } \\
\text { crops }\end{array}$ \\
\hline $\begin{array}{l}\text { - Determine number } \\
\text { of animals (livestock, } \\
\text { swine). } \\
\text { - Determine amount } \\
\text { of manure. } \\
\text { - Determine amount } \\
\text { of energy avaiable }\end{array}$ & $\begin{array}{l}\text { - Speed at which waste } \\
\text { is produced. } \\
\text { - Quantity of crop } \\
\text { hecatareas. } \\
\text { - Determine available } \\
\text { energy. }\end{array}$ & $\begin{array}{l}\text { - Determine type of } \\
\text { crop. } \\
\text { - Speed at which waste } \\
\text { is produced. } \\
\text { - Number of hectares } \\
\text { of crop. } \\
\text { - Determine available } \\
\text { energy. }\end{array}$ \\
\hline
\end{tabular}

Among the characteristics that must be analyzed for each residue, are the parameters shown in the Table 8 , which must be guaranteed to be in defined ranges, which ensure the greatest efficiency in the conversion process.

Table 8. Parameters for evaluation of biomass resources [28].

\begin{tabular}{c|c}
\hline Parameter & \multicolumn{1}{c}{ Importance } \\
\hline $\begin{array}{c}\text { LHV (Low } \\
\text { Heating }\end{array}$ & $\begin{array}{l}\text { Specifies the amount of energy delivered per mass of fuel } \\
\text { during combustion, which is expected to be a high value. }\end{array}$ \\
\hline
\end{tabular}


Maria Isabel Carvajal, Eduardo Gómez-Luna and Eduardo Marlés Sáenz/

Journal of Engineering Science and Technology Review 12 (5) (2019) 176 - 187

\begin{tabular}{c|l} 
Value) & \\
\hline $\begin{array}{c}\text { Moisture } \\
\text { content }\end{array}$ & $\begin{array}{l}\text { High moisture contents are not desired since they involve } \\
\text { low LHV }\end{array}$ \\
\hline $\begin{array}{c}\text { Volatile } \\
\text { matter }\end{array}$ & $\begin{array}{l}\text { Its amount determines how easy the resource can be } \\
\text { gasified. } \\
\text { Its increase increases the LHV } \\
\text { It varies from 5\% to 80\% depending on the origin of the } \\
\text { biomass }\end{array}$ \\
\hline Ash content & $\begin{array}{l}\text { Represents organic residues that remain after } \\
\text { combustion. } \\
\text { Low ash content is desirable to ensure higher production } \\
\text { and cleaner combustion. }\end{array}$ \\
\hline $\begin{array}{c}\text { Fixed } \\
\text { carbon }\end{array}$ & $\begin{array}{l}\text { Indicates the quality of the resource as fuel. } \\
\text { A high value indicates low content of volatile matter. }\end{array}$ \\
\hline
\end{tabular}

As it was done with the solar and wind resources, for the use and implementation of generation systems that use biomass, it is necessary to guarantee technical conditions to ensure the feasibility of the installation, which are shown in the Table 9.

Table 9. Technical characteristics to be guaranteed for the implementation of biomass resources [26]-[28].

\section{Technical characteritics}

- Select crop with greater area - Perform pre-processing and greater available energy.

- Take into account when the waste is collected

(drying) when necessary.

- Guarantee a high LHV

value in the determined range.

- Guarantee that the area used $\bullet$ Guarantee low moisture does not risk food security.

- Ensure the availability of raw material.

- Guarantee storage of raw material

- Guarantee transportation and shipment of raw materials and fuel

\section{- Diesel generator}

Regarding the technical feasibility of this resource, the Table 10 shows different technical and operational characteristics

Table 11, are presented those technical and operative characteristics.

The sizing of the battery depends on the application of the storage system and the objectives of the MG, however generally its capacity is associated with the peak demand of the system [38], [39] and the hours of autonomy established [15], [18]. It is advisable to oversize the capacity of the batteries, in a small percentage and according to the restrictions, in order to increase the life of the equipment [42].

The way in which the battery is charged significantly affects its life cycle and its discharge capacity, so the method that must be guaranteed for proper operation. It should be noted that the analysis of its feasibility does not depend on weather conditions since its power output depends on different technical factors [29]. Diesel generators are sized to cover the peak demand, also serving as a power reserve before sudden changes in the load.

The fulfillment of the technical characteristics mentioned in Table 10, guarantees the availability of this resource and the possibility of using it as a DG unit, if necessary in the MG.

Table 10. Technical and operational characteristics to be guaranteed to implement a diesel generator [29]-[33].

\begin{tabular}{|c|c|}
\hline \multicolumn{2}{|c|}{ Characteristics } \\
\hline Technical & Operative \\
\hline Guarantee fuel availability & $\begin{array}{l}\text { Guarantee the activation of Diesel } \\
\text { when strictly required: } \\
\text {-Low generation } \\
\text {-Low SOC of the battery. }\end{array}$ \\
\hline $\begin{array}{l}\text { Ensure adequate storage of fuel } \\
\text { and its transportation }\end{array}$ & $\begin{array}{l}\text { Guarantee less possible use in hours. } \\
\text {-Decrease pollution }\end{array}$ \\
\hline $\begin{array}{l}\text { Guarantee periodic maintenance } \\
\text { for correct operation }\end{array}$ & Guarantee operation in island mode \\
\hline
\end{tabular}

for correct operation

\section{$\checkmark$ Stage 4: Storage system}

Within the review conducted, it is found that batteries are the most used system of storage in MG's, as analyzed in [34], where it is evident that $95 \%$ of the reviewed cases implement batteries while the remaining percentage uses supercapacitors. This is because with this storage technique a great variety of capacities is avaible for different purposes [35]. For this reason, the methodology focuses on batteries as a storage system. It is observed that the most used type of batteries are Lead-acid batteries, which are chosen mainly because of their low cost [36].

The feasibility of the battery system falls into different technical characteristics that must be guaranteed so that the system can comply with different operational characteristics that reflect the functions that storage must fulfill. For this reason in

must be carefully chosen taking into account the battery usage pattern, granted by the optimization software in the following stages of the methodology. The battery can be charged at constant voltage or constant current, and even by pulses [43].

Within the operating characteristics of the MG is the "peak-shaving" scheme, which consists of buying energy from the grid to charge the battery at off peak moments in which there is no high demand and discharge it at peak demand times and thus not having the need to buy from the grid and contribute to reduce the peak demand seen by the main grid [41].

Table 11. Technical and operational characteristics to be guaranteed for battery storage system [15], [18], [37]-[41].

\begin{tabular}{|c|c|}
\hline \multicolumn{2}{|c|}{ Characteristics } \\
\hline Technical & Operatives \\
\hline \multirow{3}{*}{$\begin{array}{l}\text { - Sizing according to: } \\
\text {-Peak demand. } \\
\text { - Demand of critical loads. } \\
\text { - Determine hours of autonomy. }\end{array}$} & Needed \\
\hline & \\
\hline & $\begin{array}{l}\text { Guarantee stability against fluctuations generated by renewable } \\
\text { energy sources RES. }\end{array}$ \\
\hline $\begin{array}{l}\text { - Verify and guarantee the area available for implementation according to the } \\
\text { proposed capacity. }\end{array}$ & Guarantee the supply to critical loads in extreme conditions. \\
\hline - Guarantee operating conditions: Temperature and maintenance. & Store excess energy \\
\hline - Guarantee useful life by establishing charging and discharging limits: & $\begin{array}{l}\text { Guarantee the initial energy needed to transfer mode connected to } \\
\text { island mode. }\end{array}$ \\
\hline
\end{tabular}


Maria Isabel Carvajal, Eduardo Gómez-Luna and Eduardo Marlés Sáenz/

Journal of Engineering Science and Technology Review 12 (5) (2019) 176 - 187

- $90 \%$ is recommended for charging and $40 \%-20 \%$ for discharging.

- Ensure Stage of Charge SOC monitoring

- $\quad$ Avoid deep discharges or overloads.

- Determine charging method: voltage or constant current.

Peak shaving scheme application:

-Charge battery in off-peak moments

-Discharge battery at peak demand times.

Dampen power oscillations.

Power quality functions

- Determine proper configuration:

-Centralized

-Distributed

Use as a resource of black start

Frequency control

For the functions of oscillation damping and power quality, it is required that the battery within its load limits have a reserve for this function, useful when the system goes through transients during the change of operating mode [41]. Regarding the frequency control function, the battery must have a rapid response to offer fast compensation and active power [44]. While to be a black start resource, it is required that the inverter-battery system has a capacity at least equal to the largest DG unit [40].

They are shown below, in Table 12, the criteria that must be taken into account when selecting the type of battery to be implemented. Within the criteria is the use pattern, this criterion is analyzed with the assistance of the optimization software used, which shows how many times in the day the battery is charged and discharged.

Table 12. Selection criteria for storage system [43]-[46].

\begin{tabular}{l|l}
\hline \multicolumn{1}{c}{ Selection criteria } \\
\hline \multirow{3}{*}{ Economics } & - Cost per unit \\
& - O \& M Cost (Operation and Maintain) \\
\hline \multirow{5}{*}{ Technical } & - Nominal voltage \\
& - Rated current \\
& - Capacity (Ah) \\
& - Hours of autonomy \\
& - Power (kW) \\
& - Effe time in cycles \\
& - Use pattern \\
& - Quick response \\
& - Available space
\end{tabular}

\section{$\checkmark$ Stage 5: Intelligent control system}

The intelligent control system is the MG's heart, since it is in charge of complying with certain technical requirements established by the current regulations and the specific objectives of the MG. In Table 13 the different functions that the intelligent control system must fulfill, whatever its strategy or scheme, regardless of the type of MG. The user must guarantee compliance with the aforementioned functions in order to ensure technical feasibility.

Table 13. Intelligent control functions for MG's [47].

\begin{tabular}{l|l}
\hline \multicolumn{2}{c}{ Intelligent control functions for any type of MG } \\
\hline $\begin{array}{l}\text { Maintain power balance between } \\
\text { generation and demand with the help of } \\
\text { the storage system. }\end{array}$ & $\begin{array}{l}\text { Connected mode } \\
\text { - The main network is } \\
\text { Maintain voltage and frequency stability } \\
\text { in both modes of operation. }\end{array}$ \\
$\begin{array}{l}\text { Monitor and ensure that the system } \\
\text { - It is responsible for } \\
\text { works within the regulated operating }\end{array}$ & $\begin{array}{l}\text { benefits) } \\
\text { limits of voltage and frequency. }\end{array}$ \\
$\begin{array}{l}\text { Responsible for the power output of both } \\
\text { dispatchable and non-dispatchable }\end{array}$ & $\begin{array}{l}\text { delivering active and reactive } \\
\text { power. }\end{array}$ \\
$\begin{array}{l}\text { sources, to ensure stability. } \\
\text { It is responsible for the interaction with } \\
\text { the Energy Management System EMS } \\
\text { and the power flow exchange with the } \\
\text { main network. }\end{array}$ & $\begin{array}{l}\text { - Island mode: } \\
\text { Change the control philosophy according }\end{array}$ \\
\cline { 2 - 2 }
\end{tabular}

to the operation mode. Operation of protections in regulated ranges.

Scheme of redispatch of demand.

Prediction of generation of renewable DG units

The intelligent control system interacts with all the components of the system to maintain stability, which is why it has different operational characteristics or actions related to each component of the $\mathrm{MG}$, which will depend on

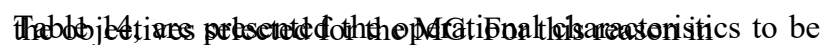
met by the control depending on the objectives of the MG, which the user must determine which to apply according to Table 1 .

Table 14. Control actions associated with specific objectives.

\begin{tabular}{|c|c|c|}
\hline \multicolumn{3}{|c|}{ Control Actions } \\
\hline $\begin{array}{l}\text { Distributed } \\
\text { Generation }\end{array}$ & Storage & Demand/Load \\
\hline $\begin{array}{l}\text { Implement PV } \\
\text { smoothing: } \\
\text {-Atenase PV system } \\
\text { variability. } \\
\text {-Apply in grid connected } \\
\text { mode. } \\
\text { Implement sun tracking } \\
\text { (PV): } \\
\text { - It is responsible for } \\
\text { changing the angle of } \\
\text { inclination of the panel } \\
\text { according to the } \\
\text { programmed. } \\
\text { Implement MPPT : } \\
\text {-Maximum Power Point } \\
\text { Traker. } \\
\text { - Look for maximum } \\
\text { efficiency point in any } \\
\text { condition. } \\
\text { Diesel control: } \\
\text {-It is activated when the } \\
\text { MG is in island mode. } \\
\text {-It is activated when } \\
\text { there is no other } \\
\text { resource available } \\
\text {-It is activated when the } \\
\text { SOC of the battery } \\
\text { exceeds the limit. } \\
\text { Inverter modifies power } \\
\text { output to maintain } \\
\text { balance. }\end{array}$ & $\begin{array}{l}\text { Perform } \\
\text { Peak-shaving for } \\
\text { economic benefit. } \\
\text { Control the "dump } \\
\text { load" for excess } \\
\text { energy. }\end{array}$ & $\begin{array}{l}\text { Send signals to users } \\
\text { to promote changes in } \\
\text { demand and obtain } \\
\text { economic benefits. }\end{array}$ \\
\hline
\end{tabular}

The intelligent control system must have a certain dispatch strategy, which establishes the limits and conditions in which the available DG units cover the demand throughout the day [20] [48]. This requirement and the functions mentioned above are different and are carried out at different scales and times, so the most used control structure is the hierarchical consisting of 3 levels [47]. In the 
Maria Isabel Carvajal, Eduardo Gómez-Luna and Eduardo Marlés Sáenz/

Journal of Engineering Science and Technology Review 12 (5) (2019) 176 - 187

same way there are two control configurations, centralized and decentralized. These different structures, strategies and

control schemes are presented in the diagram of Fig. 7.

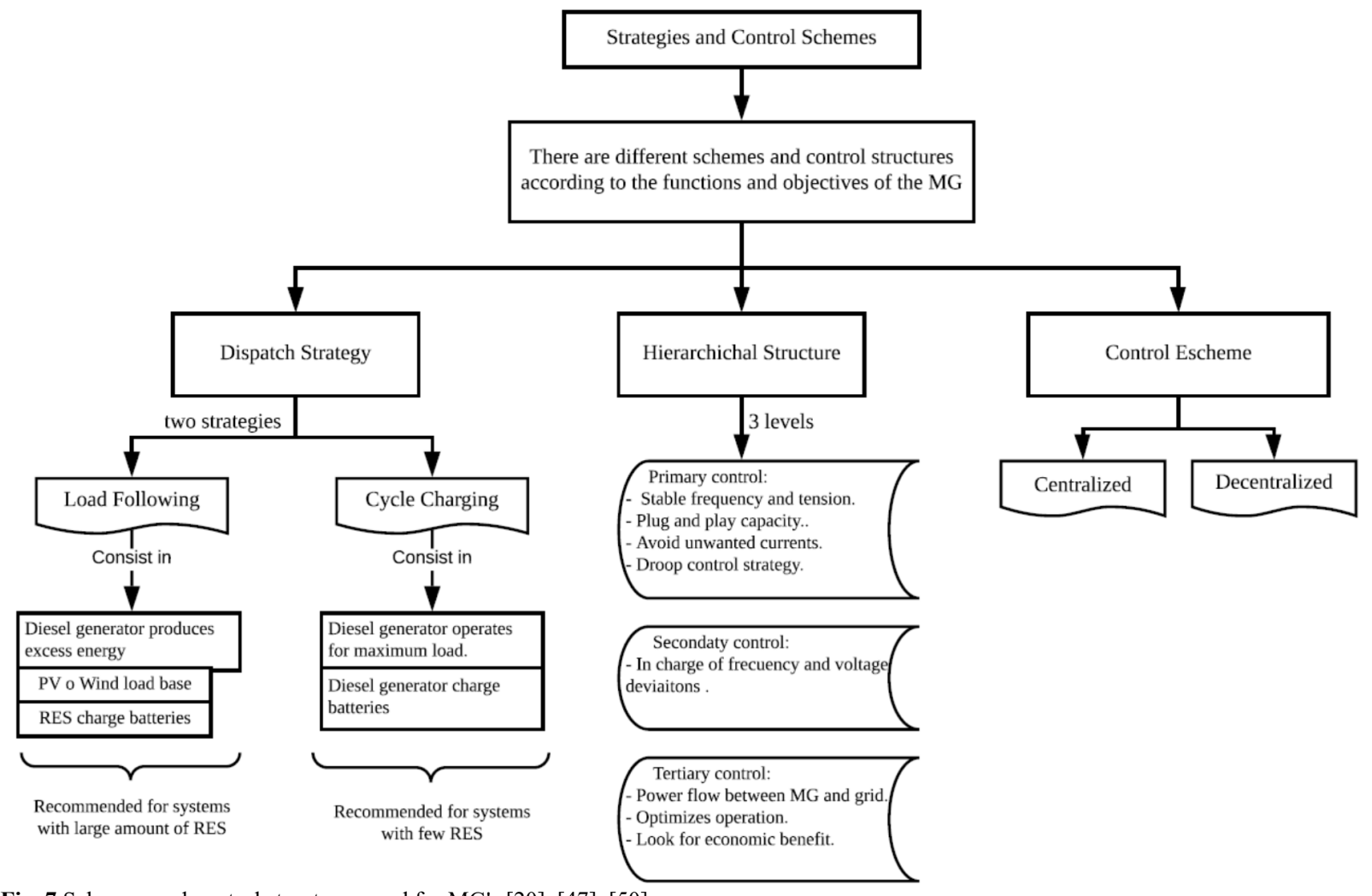

Fig. 7 Schemes and control structures used for MG's [20], [47]-[50].

\section{$\checkmark$ Stage 6. Initial configuration and optimization analysis}

The present stage determines the initial configuration of the MG to be implemented and its analysis in optimization software to obtain the final MG configuration, therefore Stage 6 is divided into Stage 6.1 and Stage 6.2.

\section{$\checkmark$ Stage 6.1: Initial configuration}

Once the elements of the MG to be implemented have been analyzed, the initial configuration is determined with the DG resources that were established as available and feasible to implement, defining the need for a back-up system, composed of a Diesel generator. This configuration becomes important when performing the software optimization process, since it determines the input data regarding the available resources and the topology of the MG.

In the diagram of Fig. 8, the use of Diesel generators is evaluated according to the specific objectives mentioned in the Table 1, showing that for remote MG's that do not have a connection to the grid and for MG's with only one renewable resource available, the presence of a Diesel generator is considered indispensable, this is because with only one available resource its capacity must be much greater to cover the demand, which would not be feasible in many cases [20]. $\checkmark$ Stage 6.2: Analysis in optimization software In order to obtain a technically feasible final configuration, it is necessary to use optimization software which is responsible for evaluating the technical-economic feasibility of the system, corroborating that the load can be met with the available resources and estimating the different costs associated with the MG. The HOMER Pro software, the

Table 16. most commonly used in the revised references for feasibility evaluations, delivers different MG configurations with their respective sizing and behavior of each component of the MG [38]. For this reason, it is necessary to determine technical and economic selection criteria, in order to determine which of the proposed configurations is the most viable according to the objectives.

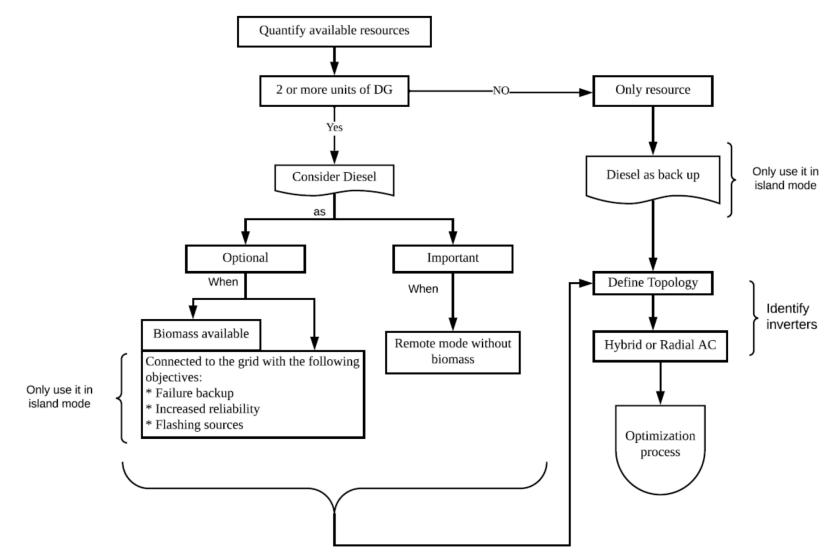

Fig. 8. Definition of the initial configuration of the MG.

They are presented in Table 15, the main economic criteria most frequently analyzed during the revised feasibility studies, which seek to complement the technical analysis carried out during the methodology. The technical selection criteria analyzed most frequently to determine the

final configuration alternative are presented in the

Table 15. Main economic selection criteria for economic feasibility in MG's [51]. 
Maria Isabel Carvajal, Eduardo Gómez-Luna and Eduardo Marlés Sáenz/

Journal of Engineering Science and Technology Review 12 (5) (2019) 176 - 187

\begin{tabular}{c|l|l}
\hline \multicolumn{1}{c}{ Mnitial cost } & Net Present Cost NPC & \multicolumn{1}{c}{$\begin{array}{c}\text { Cost of Energy } \\
\text { (COE) }\end{array}$} \\
\hline $\begin{array}{l}\text { Total cost of system } \\
\text { installation }\end{array}$ & $\begin{array}{l}\text { Costs for each } \\
\text { component: } \\
\text { - Cost of O\&M }\end{array}$ & $\begin{array}{l}\text { Average cost per kWh } \\
\text { of usable energy } \\
\text { produced by the }\end{array}$ \\
\hline
\end{tabular}

\begin{tabular}{l|l|l} 
& $\begin{array}{l}\text { - Replacement cost } \\
- \text { Fuel cost }\end{array}$ & system \\
\hline COE: Cost of Energy
\end{tabular}

COE: Cost of Energy

Table 16. Technical selection criteria

\begin{tabular}{|c|c|c|}
\hline Selection criteria & Objective & Analysis \\
\hline Renewable Factor RF & Implement RES & $\begin{array}{l}\text { Percentage of energy generated by RES } \\
\text { - Increase of RF causes greater excess of energy. } \\
\text { - Increase of RF causes increase of initial investment. } \\
\text { - Related to the amount of emissions. } \\
\text { - Higher capacity, greater reliability }\end{array}$ \\
\hline Amount of emissions & $\begin{array}{l}\text { Implement RES. } \\
\text { Reduction of emissions. }\end{array}$ & $\begin{array}{l}\text { - Increase RF, reduce emissions. } \\
\text { - It is related to Diesel operating hours. }\end{array}$ \\
\hline Storage & All objectives & $\begin{array}{l}\text { - Alternatives that do not have storage are discarded. } \\
\text { - Analyze capacity according to peak demand. } \\
\text { - Related to hours of Diesel use. } \\
\text { - Analyze the SOC during the year, if it varies or is maintained. } \\
\text { - Analyze the estimated life time according to your capacity. }\end{array}$ \\
\hline Capacity shortage & $\begin{array}{l}\text { Remote Mode } \\
\text { Increase reliability }\end{array}$ & $\begin{array}{l}\text { Refers to the percentage of load not met. } \\
\text { - Its decrease increases the installed capacity. } \\
\text { - Its decrease increases the excess energy. } \\
\text { - Affects economic criteria such as CPN and COE. } \\
\text { - It is related to the capacity of Load-Shedding. } \\
\text { - Realizes the efficient management of energy. }\end{array}$ \\
\hline Excess of energy & $\begin{array}{l}\text { Remote Mode } \\
\text { Increase reliability } \\
\text { Costs reduction } \\
\text { Fault support }\end{array}$ & $\begin{array}{l}\text { - It is related to Capacity shortage. } \\
\text { - Greater excess of energy, greater installed capacity and cost. } \\
\text { - It is a spinning reserve when increase demand. } \\
\text { - Represents economic benefit in grid connected mode. }\end{array}$ \\
\hline Diesel generator & $\begin{array}{l}\text { Increase reliability } \\
\text { Reduction of emissions }\end{array}$ & $\begin{array}{l}\text { - Analyze capacity according to peak demand. } \\
\text { - Analyze hours of use (minimum) and capacity factor. } \\
\text { - Production proportional to quantity of emissions and inverse to RF. } \\
\text { - Analyze production contributed in a day and in the year. } \\
\text { - Analyze behavior in both modes of operation of the MG. } \\
\text { - Analyze capacity of spinning reserve. }\end{array}$ \\
\hline Capacity Factor & $\begin{array}{l}\text { Reduction of emissions } \\
\text { Costs reduction }\end{array}$ & $\begin{array}{l}\text { - Represents the use of DG units } \\
\text { - It is intended to be small in Diesel units and high in renewable units. } \\
\text { - It is related to the reduction of emissions and costs.. }\end{array}$ \\
\hline Main Grid & $\begin{array}{l}\text { Costs reduction } \\
\text { Fault support }\end{array}$ & $\begin{array}{l}\text { - Analyze quantity of energy purchased from the network and energy sold to the network. } \\
\text { - Analyze when energy is bought and sold to the network. } \\
\text { - Analyze hours of operation of DG units when connected to the network vs island mode. } \\
\text { - It is related to Peak-shaving capacity and cost savings. }\end{array}$ \\
\hline
\end{tabular}

Regarding the presence of storage, the relationship between its capacity and the capacity and hours of operation of the diesel must be considered, because if the alternative has a greater capacity of batteries, therefore the diesel will operate fewer hours, generating fewer emissions and costs [33]. On the other hand, the capacity shortage criterion is related to the "load-shedding" scheme because the percentage of unsatisfied load may be greater as long as there is the possibility of load disconnection and thus maintain the stability without having to increase costs, excess energy and installed capacity [52], [53].

The excess energy generated is related to the capacity shortage criterion, since the lower the percentage of non-supplied load, the greater the excess energy [20], [53]. On the other hand, the capacity factor represents the annual percentage of generation time of each DG unit [12]. Therefore, a low service factor for Diesel generators is expected, achieving the lowest use in hours of these systems due to its high cost and contamination.

After analyzing and comparing different configuration alternatives according to the selection criteria proposed for $\mathrm{MG}$, the most appropriate alternative is chosen according to the objectives and analyzes carried out up to now.

\section{Stage 7: Sensitivity analysis and final verification}

The optimization software does not take into account various external conditions to the data entered, such as the location of the DG units, the maintenance status of the equipment, increase in load and the variation of climatic conditions, which is of great importance to perform a sensitivity analysis. A sensitivity analysis is carried out by varying those parameters for which there is no certainty. The objective is to observe how these variations affect the costs and technical characteristics of the chosen alternative and make the necessary adjustments. The most common analysis variables are solar radiation, wind speed, the number of batteries, the cost of fuel, the O\&M (Operation and Maintein) cost and the increase in average demand [30].

Once the necessary adjustments to the selected configuration are made, it is proposed to carry out a final verification, represented in the diagram of Fig. 9, in which are presented technical factors to verify for the DG units and the storage system. On the other hand, in the diagram of Fig. 10 , is presented the normative verification that must be taken into account for the implementation of an MG based on the international standard IEEE 1547 of 2018, which can be accepted by countries that do not have their own regulation referring to MG's or DG, otherwise if there is any regulation in this regard is imperative on international regulations. This diagram includes requirements for both $\mathrm{MG}$ operation modes, connected to the grid and island mode, as well as the studies required for its implementation.

Once the regulatory and technical verification has been done, a technically feasible MG configuration is obtained, so 
Maria Isabel Carvajal, Eduardo Gómez-Luna and Eduardo Marlés Sáenz/

Journal of Engineering Science and Technology Review 12 (5) (2019) 176 - 187

the next step is to carry out complementary feasibility studies, such as economic, environmental and social studies, that ensure the integral feasibility of the MG. It is suggested the use of Real-Time Simulation RTS [54]- [56], to validate the operation of the control system, protections and other components of the MG before its implementation on site.

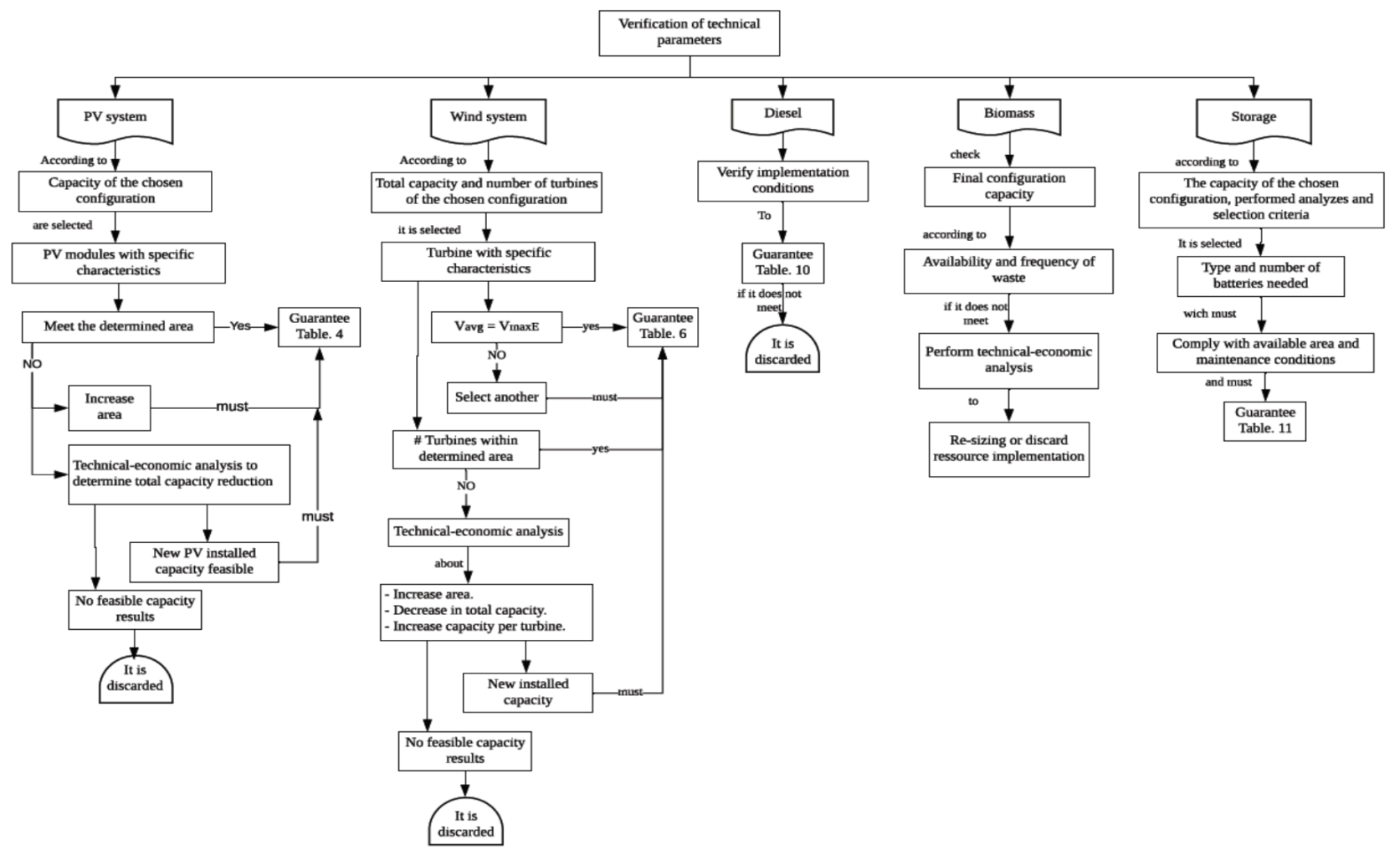

Fig. 9. Flow diagram for technical verification of $M G$ final configuration.

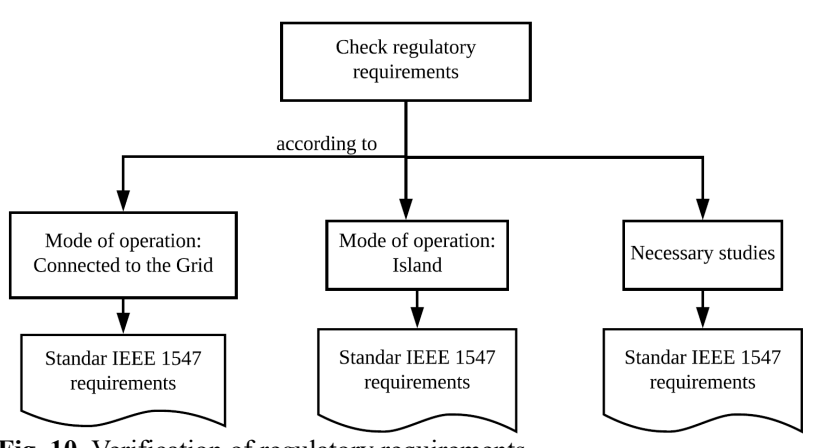

Fig. 10. Verification of regulatory requirements.

\section{Conclusions}

This article contributes to the current stage of the art that seeks to consolidate the technical feasibility assessment in the implementation of Microgrids in the power electrical system, by reviewing cases of global implementation and feasibility evaluation methodologies of Microgrids, to build a methodology composed of 8 stages that allows analyzing the technical feasibility of installing a Microgrid in a specific place, taking into account its specific objective, components and regulatory requirements.

To evaluate the feasibility of implementing a MG it is necessary to analyze both technical and economic parameters as these are directly related. To guarantee certain technical characteristics that allow the correct functioning of the system, they must be incurred, in addition to the initial investment, in different costs such as: operation and maintenance, energy, fuel and replacement costs. This relationship is evident in the analysis for the selection of the most suitable MG configuration alternative, since there are configurations that meet all the necessary requirements,

The inclusion of conventional fuel-based generation systems within the proposed methodology, is due to the intermittence of renewable energy sources and the variation of demand over time, since these generation systems represent a back up before said variations and a spinning reserve before the random increase in demand.

The selection of a renewable MG or a mixed MG (one that includes both renewable and non-renewable generation) lies mainly in the objective of the MG regarding the need for backup, reliability and security, and the economic scope of the project. For example, for a renewable $\mathrm{MG}$ whose objective is to have $0 \%$ of non-supplied load, it implies a considerable increase in the installed capacity of both generation and storage which incurs high costs however, a mixed MG can achieve that percentage reducing costs with a Diesel generation system that operates only when necessary.

When evaluating the feasibility in the implementation of Microgids, it is necessary that there is an optimization stage, due to the difficulty of determining the installed capacity of renewable resources characterized by their variability and intermittency. To achieve the above, optimization software is used, whose task is to make a comparison between the dynamics of these renewable resources and the dynamics of demand. However, it should be noted that the optimization software used does not have the last word in the composition of the MG, since it does not take into account external technical characteristics of the system.

\section{Acknowledgments}

The authors express their heartfelt thanks to the PTI S.A Company for its support in the elaboration of this paper. They also thank COLCIENCIAS for it support for Project 
58777, 2018, an approved Project to acces tax benefits, the Universidad del Valle from Colombia, for its help provided.

This is an Open Access article distributed under the terms of the

\section{References}

[1] M. Soshinskaya, W. H. J. Crijns-Graus, J. M. Guerrero, and J. C. Vasquez, "Microgrids: Experiences, barriers and success factors," Renew. Sustain. Energy Rev., vol. 40, pp. 659-672, 2014.

[2] S. Kumaravel, S. Ashok, and P. Balamurugan, "Techno-economic feasibility study of biomass based hybrid renewable energy system for microgrid application," 2012 Int. Conf. Green Technol. ICGT 2012, pp. 107-110, 2012.

[3] M. Redes and E. N. Lugares, "Metodología para el análisis de factibilidad ténica de las micro redes en lugares específicos," 2016.

[4] R. H. Lasseter, "Smart distribution: Coupled microgrids," Proc. IEEE, vol. 99, no. 6, pp. 1074-1082, 2011.

[5] C. Basford, "A Case Study of a Successful Model," pp. 95-98, 2011.

[6] C. T. T. Ho, Ruifeng Yan, T. K. Saha, and S. E. Goodwin, "Design microgrid for a distribution network: A case study of the University of Queensland," 2013 IEEE Power Energy Soc. Gen. Meet., pp. 1-5, 2013.

[7] D. Pudjianto, D. Pudjianto, C. Ramsay, C. Ramsay, G. Strbac, and G. Strbac, "Load sharing and power quality enhanced operation of a distributed microgrid," Renew. Power Gener. IET, vol. 1, no. 1, pp. 10-16, 2007.

[8] T. S. Ustun, C. Ozansoy, and A. Zayegh, "Recent developments in microgrids and example cases around the world - A review," Renew. Sustain. Energy Rev., vol. 15, no. 8, pp. 4030-4041, 2011.

[9] G. Mendes, J. Von Appen, and C. Ioakimidis, "Integrated energy microgrids for community-scale systems: Case study research in the Azores islands," 2011 8th Int. Conf. Eur. Energy Mark. EEM 11, no. May, pp. 382-387, 2011.

[10] S. Singh, M. Singh, and S. C. Kaushik, "Feasibility study of an islanded microgrid in rural area consisting of PV, wind, biomass and battery energy storage system," Energy Convers. Manag., vol. 128, pp. 178-190, 2016.

[11] B. Domenech, L. Ferrer-Martí, P. Lillo, R. Pastor, and J. Chiroque, "A community electrification project: Combination of microgrids and household systems fed by wind, PV or micro-hydro energies according to micro-scale resource evaluation and social constraints," Energy Sustain. Dev., vol. 23, pp. 275-285, 2014.

[12]A. López-González, B. Domenech, D. Gómez-Hernández, and L. Ferrer-Martí, "Renewable microgrid projects for autonomous small-scale electrification in Andean countries," Renew. Sustain. Energy Rev., vol. 79, no. February, pp. 1255-1265, 2017.

[13]A. Vides-Prado et al., "Techno-economic feasibility analysis of photovoltaic systems in remote areas for indigenous communities in the Colombian Guajira," Renew. Sustain. Energy Rev., vol. 82, no. May 2017, pp. 4245-4255, 2018.

[14]REN21, Renewables 2017: global status report, vol. 72, no. October 2016. 2017.

[15]F. H. Abanda, M. B. Manjia, K. E. Enongene, J. H. M. Tah, and C. Pettang, "Original article A feasibility study of a residential photovoltaic system in Cameroon," Sustain. Energy Technol. Assessments, vol. 17, pp. 38-49, 2016.

[16] J. M. Rey-López, P. P. Vergara-Barrios, G. A. Osma-Pinto, and G. Ordóñez-Plata, "Generalities about Design and Operation of Microgrids," Dyna, vol. 82, no. 192, pp. 109-119, 2015.

[17]H. A. Kazem, M. H. Albadi, A. H. A. Al-Waeli, A. H. Al-Busaidi, and M. T. Chaichan, "Techno-economic feasibility analysis of 1MW photovoltaic grid connected system in Oman," Case Stud. Therm. Eng., vol. 10, no. April, pp. 131-141, 2017.

[18] S. R. Sivarasu, E. Chandira Sekaran, and P. Karthik, "Development of renewable energy based microgrid project implementations for residential consumers in India: Scope, challenges and possibilities," Renew. Sustain. Energy Rev., vol. 50, pp. 256-269, 2015.

[19] T. Nacer, A. Hamidat, O. Nadjemi, and M. Bey, "Feasibility study of grid connected photovoltaic system in family farms for electricity generation in rural areas," Renew. Energy, vol. 96, pp. 305-318, 2016.

[20]H. S. Das, C. W. Tan, A. H. M. Yatim, and K. Y. Lau, "Feasibility analysis of hybrid photovoltaic / battery / fuel cell energy system for an indigenous residence in East Malaysia," Renew. Sustain.
Energy Rev., vol. 76, no. March 2016, pp. 1332-1347, 2017.

[21]A. Dabbaghiyan, F. Fazelpour, M. D. Abnavi, and M. A. Rosen, "Evaluation of wind energy potential in province of Bushehr, Iran," Renew. Sustain. Energy Rev., vol. 55, pp. 455-466, 2016.

[22]J. Ahmad et al., "Techno economic analysis of a wind-photovoltaic-biomass hybrid renewable energy system for rural electrification: A case study of Kallar Kahar," Energy, vol. 148 pp. 208-234, 2018.

[23]D. R. Drew, J. F. Barlow, and T. T. Cockerill, "Estimating the potential yield of small wind turbines in urban areas: A case study for Greater London, UK," J. Wind Eng. Ind. Aerodyn., vol. 115, pp. 104-111, 2013.

[24]K. S. R. Murthy and O. P. Rahi, “A comprehensive review of wind resource assessment," Renew. Sustain. Energy Rev., vol. 72, no. October 2016, pp. 1320-1342, 2017.

[25]H. S. Ramadan, "Wind energy farm sizing and resource assessment for optimal energy yield in Sinai Peninsula, Egypt," J. Clean. Prod., vol. 161, pp. 1283-1293, 2017.

[26] L. Cutz, P. Haro, D. Santana, and F. Johnsson, “Assessment of biomass energy sources and technologies: The case of Central America," Renew. Sustain. Energy Rev., vol. 58, pp. 1411-1431, 2016.

[27] N. Bilandzija, N. Voca, B. Jelcic, V. Jurisic, A. Matin, and M. Grubor, "Evaluation of Croatian agricultural solid biomass energy potential," Renew. Sustain. Energy Rev., vol. 93, no. May, pp. $225-230,2018$

[28] M. Hossen, A. H. M. S. Rahman, A. Sara, M. M. F. Hasan, and S. Ahmed, "Systematic assessment of the availability and utilization potential of biomass in Bangladesh," Renew. Sustain. Energy Rev., vol. 67, pp. 94-105, 2017.

[29]A. H. Hubble and T. S. Ustun, "Composition, placement, and economics of rural microgrids for ensuring sustainable development," Sustain. Energy, Grids Networks, vol. 13, pp. 1-18, 2018.

[30]A. M. Abdilahi, A. H. Mohd Yatim, M. W. Mustafa, O. T. Khalaf, A. F. Shumran, and F. Mohamed Nor, "Feasibility study of renewable energy-based microgrid system in Somaliland's urban centers," Renew. Sustain. Energy Rev., vol. 40, pp. 1048-1059, 2014.

[31]A. Ghasemi, A. Asrari, M. Zarif, and S. Abdelwahed, "Techno-economic analysis of stand-alone hybrid photovoltaic-diesel-battery systems for rural electrification in eastern part of Iran - A step toward sustainable rural development," Renew. Sustain. Energy Rev., vol. 28, pp. 456-462, 2013.

[32] M. Jayachandran and G. Ravi, "Design and Optimization of Hybrid Micro-Grid System,” Energy Procedia, vol. 117, pp. 95-103, 2017.

[33] M. Naderi, S. Bahramara, Y. Khayat, and H. Bevrani, "Optimal planning in a developing industrial microgrid with sensitive loads," Energy Reports, vol. 3, pp. 124-134, 2017.

[34] M. I. Carvajal, "Metodología para el análisis de factibilidad técnica en la instalación de micro redes," Universidad del Valle, 2018.

[35] O. Palizban, K. Kauhaniemi, and J. M. Guerrero, "Microgrids in active network management - Part I: Hierarchical control, energy storage, virtual power plants, and market participation," Renew. Sustain. Energy Rev., vol. 36, pp. 428-439, 2014.

[36]H. Xie, S. Zheng, and M. Ni, "Microgrid development in China: A method for renewable energy and energy storage capacity configuration in a megawatt-level isolated microgrid.," IEEE Electrif. Mag., vol. 5, no. 2, pp. 28-35, 2017.

[37]F. Cassias, C. Pica, L. Gentilini, V. Maryama, and D. Makohin, "Design and Implementation of a Feasible Microgrid Model in Brazil," no. October, pp. 1-9, 2014.

[38] J. Mitra and M. R. Vallem, "Determination of Storage Required to Meet Reliability Guarantees on Island-Capable MicrogridsWith Intermittent Sources," IEEE Trans. Power Syst., vol. 27, no. 4, pp. 2360-2367, 2012.

[39]K. Keskamol and N. Hoonchareon, "Sizing of battery energy storage system for sustainable energy in a remote area," Proc. 2015 IEEE Innov. Smart Grid Technol. - Asia, ISGT ASIA 2015, pp. 1-4, 2016. 
Maria Isabel Carvajal, Eduardo Gómez-Luna and Eduardo Marlés Sáenz/

Journal of Engineering Science and Technology Review 12 (5) (2019) 176 - 187

[40]SEG, "Control Principles for Blackstart and Island Operation of Microgrid," 73rd Ann. Internat. Mtg., pp. 1777-1780, 2003.

[41]E. Alegria, T. Brown, E. Minear, and R. H. Lasseter, "CERTS Microgrid Demonstration with Large- Scale Energy Storage and Renewable Generation," IEEE Trans. Smart Grid, vol. 5, no. 2, pp. $1-7,2013$.

[42] "Surrette Rolls 6-CS-25PS 1150Ah, 6V Deep Cycle Battery." .

[43]R. Baxter, N. Hastings, A. Law, and E. J. . Glass, "Comparison of Lead-Acid and Lithium Ion Batteries for Stationary Storage in Off-Grid Energy Systems," Anim. Genet., vol. 39, no. 5, pp. 561-563, 2008.

[44]P. Mercier, R. Cherkaoui, S. Member, and A. Oudalov, "Optimizing a Battery Energy Storage System for Primary Frequency Control," IEEE Trans. Power Syst., vol. 22, no. 3, pp. 1259-1266, 2007.

[45]A. H. Fathima and K. Palanisamy, "Optimization in microgrids with hybrid energy systems - A review," Renew. Sustain. Energy Rev., vol. 45, pp. 431-446, 2015.

[46]R. Garmabdari, M. Moghimi, F. Yang, J. Lu, H. Li, and Z. Yang, "Optimisation of battery energy storage capacity for a grid-tied renewable microgrid," 2017 IEEE Innov. Smart Grid Technol. Asia Smart Grid Smart Community, ISGT-Asia 2017, pp. 1-6, 2018.

[47]A. Bidram and A. Davoudi, "Hierarchical structure of microgrids control system," IEEE Trans. Smart Grid, vol. 3, no. 4, pp. 1963-1976, 2012.

[48] K. K. Shah, A. S. Mundada, and J. M. Pearce, "Performance of U.S. hybrid distributed energy systems: Solar photovoltaic, battery and combined heat and power," Energy Convers. Manag., vol. 105, pp. 71-80, 2015.

[49]C. Parthasarathy, “Optimal Sizing of Energy Storage System and their Impacts in Hybrid Microgrid Environmet," pp. 3-8, 2017.

[50]B. T. Jiang et al., “A Microgrid Test Bed in Singapore,” pp. 74-82, 2017.

[51]A. Haghighat Mamaghani, S. A. Avella Escandon, B. Najafi, A. Shirazi, and F. Rinaldi, "Techno-economic feasibility of photovoltaic, wind, diesel and hybrid electrification systems for off-grid rural electrification in Colombia," Renew. Energy, vol. 97, pp. 293-305, 2016.

[52]F. C. Robert, U. Ramanathan, Mukundan, P. Durga, and R. Mohan, "When academia meets rural India: Lessons learnt from a MicroGrid implementation," GHTC 2016 - IEEE Glob. Humanit. Technol. Conf. Technol. Benefit Humanit. Conf. Proc., pp. 156-163, 2016.

[53] O. Hafez and K. Bhattacharya, "Optimal planning and design of a renewable energy based supply system for microgrids," Renew. Energy, vol. 45, pp. 7-15, 2012.

[54]E. Gomez-Luna, J. E. C. Becerra, and E. M. Sáenz, “Current Status and Future Trends in Protection, Control and Communications Testing in Electrical Grids using Real - time Simulation," J. Eng. Sci. Technol. Rev., vol. 11, no. 4, pp. 204-214, 2018.

[55]E. Gomez-Luna, L. Palacios-Bocanegra and John E. Candelo-Becerra, "Real-time Simulation with OPAL-RT Technologies and Applications for Control and Protection Schemes in Electrical Networks" J. Eng. Sci. Technol. Rev., vol. 12, no. 3, pp. 136-144, 2019.

[56]J. Martín Guardiola M., E. Gómez Luna, E. Marlés Sáenz and J. Armando De la Cruz SaavedraL, "The Why of Adaptive Protections in Modern Electrical Networks" Ingeniería e Investigación, Volumen 39, Issue 2, pp. 1-11, 2019. 